\title{
Plot size and number of replications in Sudan grass
}

\section{Tamanho de parcela e número de repetições em capim-sudão}

\author{
Alberto Cargnelutti Filho ${ }^{1 *}$; Cirineu Tolfo Bandeira ${ }^{2}$; Gabriela Görgen Chaves ${ }^{2}$; \\ Jéssica Andiara Kleinpaul'3; Rafael Vieira Pezzini²; Ismael Mario Márcio Neu3; \\ Andréia Procedi ${ }^{4}$; Rosana Marzari Thomasi ${ }^{4}$
}

\begin{abstract}
Highlights:
We define experimental plans for the crop of Sudan grass.

We use methodologies based on data from uniformity trials.

We provide information to improve experimental precision in Sudan grass.
\end{abstract}

\begin{abstract}
The aim of this study was to determine the optimal plot size and the number of replications to evaluate fresh weight in Sudan grass [Sorghum sudanense (Piper) Stapf.]. Twenty-six uniformity trials were carried out in two cultivars (BRS Estribo and CG Farrapo), in four sowing seasons (20 Dec, 20 Jan, $7 \mathrm{Feb}$ and $24 \mathrm{Feb}$ ) and two methods for evaluating fresh weight (cutting and at flowering). The fresh weight was evaluated in 936 basic experimental units (BEU) $(26$ trials $\times 36 \mathrm{BEU}$ per trial). One BEU comprised three rows of plants, $1 \mathrm{~m}$ in length $\left(1.2 \mathrm{~m}^{2}\right)$. The optimal plot size was determined using the maximum curvature method of the model of the coefficient of variation. For experiments in a completely randomised or randomised block design, in combinations of number of treatments and levels of experimental precision, the number of replications was determined by an iterative process. The optimal plot size to evaluate fresh weight in Sudan grass is $7.95 \mathrm{~m}^{2}$. Eight replications, to evaluate up to 50 treatments in a completely randomised or randomised block design, are sufficient to identify as significant at $0.05 \%$ probability by Tukey's test, differences between the mean value of each treatment of $30.2 \%$ of the mean value of the experiment.
\end{abstract}

Key words: Agricultural experimentation. Experimental planning. Experimental precision. Sorghum sudanense (Piper) Stapf.

\section{Resumo}

Os objetivos deste trabalho foram determinar o tamanho ótimo de parcela e o número de repetições, para avaliar a massa de matéria fresca de capim-sudão [Sorghum sudanense (Piper) Stapf.]. Foram realizados 26 ensaios de uniformidade com duas cultivares (BRS Estribo e CG Farrapo), em quatro épocas de semeadura (20 de dezembro; 20 de janeiro; 7 de fevereiro; e 24 de fevereiro) e sob duas formas de avaliação da massa de matéria fresca (em cortes e somente no florescimento). A massa de

1 Prof., Universidade Federal de Santa Maria, UFSM, Santa Maria, RS, Brasil. E-mail: alberto.cargnelutti.filho@gmail.com

2 Mestres em Agronomia, Programa de Pós-Graduação em Agronomia, UFSM, Santa Maria, RS, Brasil. E-mail: cirineutolfobandeira@gmail.com; gabrielachaves94@gmail.com; rvpezzini@hotmail.com

3 Discentes do Curso de Doutorado do Programa de Pós-Graduação em Agronomia, UFSM, Santa Maria, RS, Brasil. E-mail: kleinpauljessica@gmail.com; ismaelmmneu@hotmail.com

4 Discentes, Curso de Graduação em Agronomia, UFSM, Santa Maria, RS, Brasil. E-mail: deiaprocedi123@gmail.com; rosanamthomasi@hotmail.com

* Author for correspondence 
matéria fresca foi avaliada em 936 unidades experimentais básicas (UEB) (26 ensaios $\times 36$ UEB por ensaio). A UEB foi formada por três fileiras de plantas com $1 \mathrm{~m}$ de comprimento $\left(1,2 \mathrm{~m}^{2}\right)$. O tamanho ótimo de parcela foi determinado por meio do método da curvatura máxima do modelo do coeficiente de variação. O número de repetições, para experimentos nos delineamentos inteiramente casualizado e blocos casualizados, em combinações de número de tratamentos e níveis de precisão experimental, foi determinado por processo iterativo. O tamanho ótimo de parcela para avaliar a massa de matéria fresca de capim-sudão é $7,95 \mathrm{~m}^{2}$. Oito repetições, para avaliar até 50 tratamentos, nos delineamentos inteiramente casualizado e blocos casualizados, são suficientes para identificar, como significativas a 0,05 de probabilidade, pelo teste de Tukey, diferenças entre médias de tratamentos de 30,2\% da média do experimento.

Palavras-chave: Experimentação agrícola. Planejamento experimental. Precisão experimental. Sorghum sudanense (Piper) Stapf.

\section{Introduction}

Sudan grass [Sorghum sudanense (Piper) Stapf.] is a summer annual species belonging to family Poaceae. The species is considered rustic, adapting well to different environments, including acidic soils and soils of low fertility, and tolerating heat and water deficit. Its main use is in animal feed, in the form of green forage, silage or hay (Arenhardt et al., 2015; Silveira, Sant'anna, Montardo, \& Trentin, 2015; Arenhardt et al., 2016). It is also used for ground cover, due to the degree of cover it provides, and because of the suppressive effect it has on weeds (Borges, Freitas, Mateus, Sá, \& Alves, 2014).

Promising characteristics have been pointed out in the BRS Estribo (Silveira et al., 2015), CG Picaço (Arenhardt et al., 2015) and CG Farrapo (Arenhardt et al., 2016) cultivars. The BRS Estribo cultivar, developed by Embrapa, has such characteristics as resistance to trampling and a dry matter productivity of $13.6 \mathrm{Mg} \mathrm{ha}^{-1}$ (Silveira et al., 2015). The CG Picaço cultivar, in the average of six environments (two locations in the state of Rio Grande do Sul and one in Santa Catarina $\times$ two agricultural years), had a fresh weight of $92.726 \mathrm{Mg} \mathrm{ha}^{-1}$, a dry weight of $18.486 \mathrm{Mg} \mathrm{ha}^{-1}$ and grain yield of $2.955 \mathrm{Mg}$ ha $^{-1}$ (Arenhardt et al., 2015). In those same six environments, the CG Farrapo cultivar had a fresh weight of $84.341 \mathrm{Mg} \mathrm{ha}^{-1}$, a dry weight of 15.776 $\mathrm{Mg} \mathrm{ha}^{-1}$ and grain yield of $3.866 \mathrm{Mg} \mathrm{ha}^{-1}$ (Arenhardt et al., 2016). Fresh and dry weights in Sudan grass (in the BRS Estribo cultivar) of 32.00 and $11.00 \mathrm{Mg}$ $\mathrm{ha}^{-1}$ respectively, were obtained in the study by Aker et al. (2016).

For the results to be reliable when evaluating these species, it is important to plan the experiments and determine the optimal plot size and number of replications. Research on Sudan grass and other forage and ground-cover species (Penna et al., 2010; Borges et al., 2014; Arenhardt et al., 2015, 2016; Aker et al., 2016) has been carried out using different plot sizes and number of replications, and, in general, has pointed out the promising characteristics of Sudan grass.

In evaluating six sorghum hybrids with Sudan grass, plots of four rows were used, with a length of $5 \mathrm{~m}$ and spaced $0.35 \mathrm{~m}$ between rows, giving a total of $7 \mathrm{~m}^{2}(1.4 \mathrm{~m} \times 5 \mathrm{~m})$ (Penna et al., 2010). To evaluate Sudan grass (Sorghum sudanense) and four other ground-cover plants, in addition to the control treatment with spontaneous vegetation, Borges et al. (2014) used plots of $27 \mathrm{~m}^{2}(2.7 \mathrm{~m} \times 10$ $\mathrm{m})$. The CG Picaço (Arenhardt et al., 2015) and CG Farrapo (Arenhardt et al., 2016) cultivars of Sudan grass were distributed in plots of $5 \mathrm{~m}^{2}(1 \mathrm{~m} \times 5 \mathrm{~m})$, where the fresh and dry weight was quantified in a working area of $1 \mathrm{~m}^{2}$. Evaluating Sudan grass (the BRS Estribo cultivar) and 13 other cover plants, in addition to an area of fallow, on the physiological and agronomic properties of maize in the southwest of the Amazon, the authors used plots of five rows, 
$10 \mathrm{~m}$ in length at a spacing of $0.225 \mathrm{~m}$ between rows $\left(11.25 \mathrm{~m}^{2}\right)$, with a working area of the two central rows, each $8 \mathrm{~m}$ in length $\left(3.6 \mathrm{~m}^{2}\right)$ (Aker et al., 2016). For these studies, four replications were used (Penna et al., 2010; Borges et al., 2014; Arenhardt et al., 2015, 2016; Aker et al., 2016) in a randomised block design.

Uniformity trials for agricultural crops (blank experiments) are characterised by the nonapplication of treatments and consistent execution of each procedure (soil preparation, base and cover fertilisation, seeding, the control of pests, diseases and weeds, and other cropping treatments) throughout the experimental area during the experiment. In such trials, it is possible to collect data from basic experimental units of the smallest possible size, and from these, to determine the optimal plot size and number of replications. The optimal plot size can be determined by the maximum curvature method of the model of the coefficient of variation (Paranaíba, Ferreira, \& Morais, 2009), and the number of replications by the methodology described in Cargnelutti et al. (2014). These two methodologies have been used to determine the optimal plot size and the number of replications to evaluate fresh weight in black oats (Cargnelutti et al., 2014) and millet (Burin et al., 2015 ; Burin, Cargnelutti, Alves, Toebe, \& Kleinpaul, 2016), fresh and dry weight in white oats (Lavezo et al., 2018) and rye (Chaves et al., 2018b), and grain yield in white oats (Lavezo et al., 2017) and rye (Chaves et al., 2018a).

Based on the available literature, it is understood that from uniformity trials comprising a combination of cultivars, sowing seasons and methods of evaluating fresh weight, it is possible to determine the plot size and the number of replications to be used as a reference in planning future experiments involving Sudan grass. As such, the aim of this study was to determine the optimal plot size and the number of replications to evaluate fresh weight in Sudan grass [Sorghum sudanense (Piper) Stapf.].

\section{Material and Methods}

Twenty-six uniformity trials were carried out on a crop of Sudan grass [Sorghum sudanense (Piper) Stapf.] in an experimental area of the Department of Plant Science, at the Federal University of Santa Maria, in Santa Maria, Rio Grande do Sul, located at $29^{\circ} 42^{\prime} \mathrm{S}$ and $53^{\circ} 49^{\prime} \mathrm{W}$, at an altitude of $95 \mathrm{~m}$. According to the Köppen classification, the climate in the region is type Cfa, humid subtropical with hot summers and no dry season (Alvares, Stape, Sentelhas, Gonçalves, \& Sparovek, 2013), and the local soil is classified as a Dystrophic Red Arenic Argisol (Santos et al., 2013).

The uniformity trials comprised a combination of two cultivars (BRS Estribo and CG Farrapo), four sowing seasons (20/12/2016, 20/01/2017, 07/02/2017 and 24/02/2017) and two methods of evaluating the fresh weight (cutting and at flowering). In each trial, the Sudan grass was sown in rows spaced $0.4 \mathrm{~m}$ apart, at a density of $25 \mathrm{~kg} \mathrm{ha}^{-1}$ of viable seeds (Silveira et al., 2015; Arenhardt et al., 2016). For the trials in which cutting was carried out, fertilisation with $67.5 \mathrm{~kg} \mathrm{ha}^{-1} \mathrm{~N}$ was repeated after each cut to stimulate sprouting. The remaining treatments were as recommended for the crop.

The total area of each uniformity trial was $9 \mathrm{~m} \times$ $8 \mathrm{~m}\left(72 \mathrm{~m}^{2}\right)$, made up of 20 rows, $9 \mathrm{~m}$ in length. The working area of each uniformity trial (the central area for the evaluations) was $6 \mathrm{~m} \times 7.2 \mathrm{~m} \mathrm{(43.2}$ $\mathrm{m}^{2}$ ), consisting of 18 rows, each with a length of 6 $\mathrm{m}$. Each uniformity trial was divided into 36 basic experimental units (BEU) of $1 \mathrm{~m} \times 1.2 \mathrm{~m}\left(1.2 \mathrm{~m}^{2}\right)$, forming a matrix of six rows and six columns. One BEU comprised 3 rows, $1 \mathrm{~m}$ in length.

For eight of the uniformity trials (two cultivars $x$ four sowing seasons), the fresh weight was evaluated by cutting. When the plants reached 100 $\mathrm{cm}$ in height, they were cut $25 \mathrm{~cm}$ from the ground. The fresh matter from each BEU was weighed and removed from the experimental area to allow for plant regrowth and to simulate animal grazing. As the plants again reached a height of $100 \mathrm{~cm}$, the 
same procedure was repeated. Therefore, for each cultivar (BRS Estribo and CG Farrapo), four, three, one and one cuts were made for each sowing season respectively: 20/12/2016 (season 1), 20/01/2017 (season 2), 07/02/2017 (season 3) and 24/02/2017 (season 4) (Table 1). In this study, each cut (evaluation) was considered one uniformity trial. As such, under the cutting management, the eight uniformity trials were considered as 18 uniformity trials.

\section{Table 1}

Number of uniformity trial, sowing season, date of sowing, date of emergence, date of fresh weight evaluation, number of days after sowing (DAS) and method of fresh weight evaluation, in two cultivars (BRS Estribo and CG Farrapo) of Sudan grass [Sorghum sudanense (Piper) Stapf.]

\begin{tabular}{cccccccc}
\hline Trial $^{(1)}$ & Cultivar & Season & Sowing Date & Emergence & Evaluation & DAS & Method of evaluation \\
\hline 1 & BRS Estribo & 1 & $20 / 12 / 2016$ & $29 / 12 / 2016$ & $26 / 01 / 2017$ & 37 & Cut 1 \\
2 & BRS Estribo & 1 & $20 / 12 / 2016$ & $29 / 12 / 2016$ & $14 / 02 / 2017$ & 56 & Cut 2 (Regrowth) \\
3 & BRS Estribo & 1 & $20 / 12 / 2016$ & $29 / 12 / 2016$ & $14 / 03 / 2017$ & 84 & Cut 3 (Regrowth) \\
4 & BRS Estribo & 1 & $20 / 12 / 2016$ & $29 / 12 / 2016$ & $13 / 04 / 2017$ & 114 & Cut 4 (Regrowth) \\
5 & BRS Estribo & 1 & $20 / 12 / 2016$ & $29 / 12 / 2016$ & $20 / 02 / 2017$ & 62 & Flowering \\
6 & CG Farrapo & 1 & $20 / 12 / 2016$ & $29 / 12 / 2016$ & $26 / 01 / 2017$ & 37 & Cut 1 \\
7 & CG Farrapo & 1 & $20 / 12 / 2016$ & $29 / 12 / 2016$ & $14 / 02 / 2017$ & 56 & Cut 2 (Regrowth) \\
8 & CG Farrapo & 1 & $20 / 12 / 2016$ & $29 / 12 / 2016$ & $14 / 03 / 2017$ & 84 & Cut 3 (Regrowth) \\
9 & CG Farrapo & 1 & $20 / 12 / 2016$ & $29 / 12 / 2016$ & $13 / 04 / 2017$ & 114 & Cut 4 (Regrowth) \\
10 & CG Farrapo & 1 & $20 / 12 / 2016$ & $29 / 12 / 2016$ & $20 / 02 / 2017$ & 62 & Flowering \\
11 & BRS Estribo & 2 & $20 / 01 / 2017$ & $02 / 02 / 2017$ & $24 / 02 / 2017$ & 35 & Cut 1 \\
12 & BRS Estribo & 2 & $20 / 01 / 2017$ & $02 / 02 / 2017$ & $15 / 03 / 2017$ & 54 & Cut 2 (Regrowth) \\
13 & BRS Estribo & 2 & $20 / 01 / 2017$ & $02 / 02 / 2017$ & $13 / 04 / 2017$ & 83 & Cut 3 (Regrowth) \\
14 & BRS Estribo & 2 & $20 / 01 / 2017$ & $02 / 02 / 2017$ & $31 / 03 / 2017$ & 70 & Flowering \\
15 & CG Farrapo & 2 & $20 / 01 / 2017$ & $30 / 01 / 2017$ & $24 / 02 / 2017$ & 35 & Cut 1 \\
16 & CG Farrapo & 2 & $20 / 01 / 2017$ & $30 / 01 / 2017$ & $15 / 03 / 2017$ & 54 & Cut 2 (Regrowth) \\
17 & CG Farrapo & 2 & $20 / 01 / 2017$ & $30 / 01 / 2017$ & $13 / 04 / 2017$ & 83 & Cut 3 (Regrowth) \\
18 & CG Farrapo & 2 & $20 / 01 / 2017$ & $30 / 01 / 2017$ & $31 / 03 / 2017$ & 70 & Flowering \\
19 & BRS Estribo & 3 & $07 / 02 / 2017$ & $14 / 02 / 2017$ & $15 / 03 / 2017$ & 36 & Cut 1 \\
20 & BRS Estribo & 3 & $07 / 02 / 2017$ & $14 / 02 / 2017$ & $04 / 05 / 2017$ & 86 & Flowering \\
21 & CG Farrapo & 3 & $07 / 02 / 2017$ & $14 / 02 / 2017$ & $15 / 03 / 2017$ & 36 & Cut 1 \\
22 & CG Farrapo & 3 & $07 / 02 / 2017$ & $14 / 02 / 2017$ & $04 / 05 / 2017$ & 86 & Flowering \\
23 & BRS Estribo & 4 & $24 / 02 / 2017$ & $04 / 03 / 2017$ & $13 / 04 / 2017$ & 48 & Cut 1 \\
24 & BRS Estribo & 4 & $24 / 02 / 2017$ & $04 / 03 / 2017$ & $22 / 05 / 2017$ & 87 & Flowering \\
25 & CG Farrapo & 4 & $24 / 02 / 2017$ & $04 / 03 / 2017$ & $13 / 04 / 2017$ & 48 & Cut 1 \\
26 & CG Farrapo & 4 & $24 / 02 / 2017$ & $04 / 03 / 2017$ & $22 / 05 / 2017$ & 87 & Flowering \\
\hline
\end{tabular}

(1) Each uniformity trial of $6 \mathrm{~m} \times 7.2 \mathrm{~m}\left(43.2 \mathrm{~m}^{2}\right)$ was divided into 36 basic experimental units (BEU) of $1 \mathrm{~m} \times 1.2 \mathrm{~m}\left(1.2 \mathrm{~m}^{2}\right)$ to form a matrix of six rows and six columns.

In the other eight uniformity trials (two cultivars $\times$ four sowing seasons), the fresh weight was evaluated at flowering. The plants were cut close to the ground, and the fresh matter from each BEU was weighed and kept in the experimental area, simulating ground-cover management. 
For each uniformity trial, the following were determined from the fresh-weight data of the 36 BEU: the first order spatial autocorrelation coefficient $(\rho)$, the variance $\left(\mathrm{s}^{2}\right)$, the mean $(\mathrm{m})$ and the coefficient of variation for the trial $(\mathrm{CV})$ as a percentage. The estimate of $\rho$ was obtained from the mean value of the estimates of $\rho$ in the direction of the rows and of $\rho$ in the direction of the columns, as per Paranaíba et al. (2009). To estimate $\rho$ in the direction of the rows, the circuit started at the BEU located in row 1 , column 1 , up to row 1 , column 6 , returning from row 2 , column 6 , to row 2 , column 1 , and so on, until completing the circuit with the BEU located in row 6 , column 1. To estimate $\rho$ in the direction of the columns, the circuit began at the BEU in row 1, column 1, up to row 6 , column 1 , returning from row 6 , column 2 , to row 1 , column 2 , and so on, until completing the circuit at the BEU located at row 1 , column 6 .

In each of the 26 trials, the optimal plot size (Xo) was determined by the maximum curvature method of the model of the coefficient of variation, from the expression Xo $=10 \sqrt[3]{2\left(1-\rho^{2}\right) \mathrm{s}^{2} \mathrm{~m}} / \mathrm{m}$ (Paranaíba et al., 2009). The coefficient of variation at the optimal plot size $\left(\mathrm{CV}_{\mathrm{Xo}_{\mathrm{o}}}\right)$, was then determined as a percentage, from the expression $\mathrm{CV}_{\mathrm{X}_{\mathrm{o}}}=\sqrt{\left(1-\rho^{2}\right) \mathrm{s}^{2} / \mathrm{m}^{2}} / \sqrt{\mathrm{Xo}} \times 100$ (Paranaíba et al., 2009). In this way, estimates of $\rho, \mathrm{s}^{2}, \mathrm{~m}, \mathrm{CV}, \mathrm{Xo}$ and $\mathrm{CV}_{\mathrm{Xo}}$ were obtained for each uniformity trial.

The mean values of $\rho, s^{2}, m, C V, X o$ and $C_{\text {Xo }}$ were compared between the cultivars (BRS Estribo vs CG Farrapo), between the sowing seasons (1 vs 2, 1 vs 3,1 vs 4,2 vs 3,2 vs 4 and 3 vs 4 ) and between the methods of evaluating the fresh weight (cutting vs flowering). These comparisons were made using Student's t-test (bilateral) for independent samples, at a significance level of $5 \%$, with the results of these comparisons represented by letters next to the mean values.

The minimum significant difference (d) from Tukey's test, expressed as a percentage of the mean value of the experiment, is estimated by the expression $\mathrm{d}=\left(\mathrm{q}_{\alpha(\mathrm{i} ; \mathrm{DFF})} \sqrt{\mathrm{MSE} / \mathrm{r}}\right) / \mathrm{m} \times 100, \quad$ where $\mathrm{q}_{\alpha(\mathrm{i} ; \mathrm{DFE})}$ is the critical value of Tukey's test at level $\alpha$ probability of error $(\alpha=0.05$ in this study), i is the number of treatments, DFE is the number of degrees of freedom of the error, i.e. $\mathrm{i}(\mathrm{r}-1)$ for the completely randomised design and (i-1)(r-1) for the randomised block design, MSE is the mean squared error, $r$ is the number of replications, and $m$ is the mean value of the experiment. Substituting the expression of the coefficient of experimental variation $(\mathrm{CV}=\sqrt{\mathrm{MSE}} / \mathrm{m} \times 100)$ as a percentage in the expression for calculating $\mathrm{d}$ and isolating $\mathrm{r}$ gives $\mathrm{r}=\left(\mathrm{q}_{\alpha(i \mathrm{i} \text { DFE }} \mathrm{CV} / \mathrm{d}\right)^{2}$. In this study, CV is expressed as a percentage and corresponds to $\mathrm{CV}_{\mathrm{Xo}}$, as this is the expected $\mathrm{CV}$ for the experiment with the optimal determined plot size (Xo) (Cargnelutti et al., 2014). From the largest value for $\mathrm{CV}_{\mathrm{Xo}_{\mathrm{o}}}$ among the 26 uniformity trials, the number of replications (r) was then determined by an iterative process until convergence, for the experiments in a completely randomised or randomised block design, in scenarios formed by combinations of $\mathrm{i}(\mathrm{i}=3,4, \ldots, 50)$ and $\mathrm{d}$ $(d=10 \%, 12 \%, 14 \%, 16 \%, 18 \%, 20 \%, 22 \%, 24 \%$, $26 \%, 28 \%, 30 \%$ ). Lower values of $\mathrm{d}$ indicate greater experimental precision, i.e. smaller differences between the mean values of the treatments will be considered significant and vice versa. The statistical analysis was carried out using Microsoft Office Excel $^{\circledR}$ and the R (R Development Core Team [R], 2018) and Genes (Cruz, 2016) software.

\section{Results and Discussion}

Under the cutting management, the total fresh weight of the BRS Estribo cultivar was 49.00, $36.32,14.42$ and $13.56 \mathrm{Mg} \mathrm{ha}^{-1}$ and of the CG Farrapo cultivar, 37.69, 37.82, 14.21 and 19.85 $\mathrm{Mg} \mathrm{ha}^{-1}$, for seasons $1,2,3$ and 4 respectively. The greater amount of fresh matter in the first two seasons is explained by better plant development, which allowed for a greater number of cuts to be made, i.e. four cuts for season 1 and three cuts for season 2. Whereas in seasons 3 and 4 there was no 
plant regrowth after the first cut. These results show that with the delay in sowing, there was a reduction in the fresh weight of these cultivars.

Under the ground-cover management, i.e. at flowering, the fresh weight of the BRS Estribo cultivar, was $46.57,37.15,30.40$ and $21.83 \mathrm{Mg}$ $\mathrm{ha}^{-1}$ and of the CG Farrapo cultivar, 49.41, 37.35, 32.28 and $24.69 \mathrm{Mg} \mathrm{ha}^{-1}$, for seasons 1, 2, 3 and 4 respectively (Table 2). As such, it can be inferred that the two cultivars showed a similar reduction in fresh weight with the delay in sowing, and that the first two seasons (20 Dec and 20 Jan) would be more favourable to plant development compared to the last two seasons (7 Feb and $24 \mathrm{Feb}$ ). According to Silveira et al. (2015), a late sowing season (January and February) can expose plants to such weather conditions as a reduction in temperature and photoperiod that can limit growth, affecting the height, the cycle, and the production of fresh matter.

Table 2

First order spatial autocorrelation coefficient $(\rho)$, variance $\left(s^{2}\right)$, mean $(\mathrm{m})$, coefficient of variation for the trial (CV), optimal plot size (Xo) and coefficient of variation at the optimal plot size $\left(\mathrm{CV}_{\mathrm{x}_{0}}\right)$, for fresh weight in Sudan grass [Sorghum sudanense (Piper) Stapf.], in grams per basic experimental unit (BEU) of 1 m $\times 1.2$ m (1.2 m²), in 26 uniformity trials comprising a combination of two cultivars (BRS Estribo and CG Farrapo), four sowing seasons $(20 / 12 / 2016,20 / 01 / 2017,07 / 02 / 2017$ and 24/02/2017) and two methods to evaluate the fresh weight (FW, cutting and at flowering)

\begin{tabular}{|c|c|c|c|c|c|c|c|c|c|c|c|}
\hline Trial $^{(1)}$ & Cultivar & Season & $\begin{array}{l}\text { Sowing } \\
\text { Date }\end{array}$ & $\begin{array}{c}\text { FW } \\
\text { Management }\end{array}$ & $\rho$ & $s^{2}$ & $\mathrm{~m}$ & $\begin{array}{l}\text { CV } \\
(\%)\end{array}$ & $\begin{array}{c}\text { Xo } \\
\text { (BEU) }\end{array}$ & $\begin{array}{c}\text { Xo } \\
\left(\mathrm{m}^{2}\right) \\
\end{array}$ & $\begin{array}{l}\mathrm{CV}_{\mathrm{Xo}_{\mathrm{o}}} \\
(\%)\end{array}$ \\
\hline 1 & BRS Estribo & 1 & $20 / 12 / 2016$ & Cut & 0.29 & 448,762 & 2,776 & 24.13 & 4.74 & 5.69 & 10.60 \\
\hline 2 & BRS Estribo & 1 & $20 / 12 / 2016$ & Cut & 0.44 & 100,320 & 1,012 & 31.28 & 5.41 & 6.49 & 12.09 \\
\hline 3 & BRS Estribo & 1 & $20 / 12 / 2016$ & Cut & 0.56 & 144,736 & 1,132 & 33.62 & 5.39 & 6.46 & 12.04 \\
\hline 4 & BRS Estribo & 1 & $20 / 12 / 2016$ & Cut & 0.53 & 130,921 & 961 & 37.66 & 5.88 & 7.05 & 13.14 \\
\hline 5 & BRS Estribo & 1 & $20 / 12 / 2016$ & Flowering & 0.31 & 966,278 & 5,588 & 17.59 & 3.82 & 4.59 & 8.55 \\
\hline 6 & CG Farrapo & 1 & $20 / 12 / 2016$ & Cut & 0.56 & 310,181 & 1,225 & 45.46 & 6.57 & 7.88 & 14.68 \\
\hline 7 & CG Farrapo & 1 & $20 / 12 / 2016$ & Cut & 0.41 & 173,400 & 997 & 41.76 & 6.63 & 7.95 & 14.82 \\
\hline 8 & CG Farrapo & 1 & $20 / 12 / 2016$ & Cut & 0.23 & 147,546 & 1,070 & 35.91 & 6.25 & 7.50 & 13.98 \\
\hline 9 & CG Farrapo & 1 & $20 / 12 / 2016$ & Cut & 0.62 & 221,547 & 1,231 & 38.25 & 5.64 & 6.77 & 12.61 \\
\hline 10 & CG Farrapo & 1 & $20 / 12 / 2016$ & Flowering & 0.00 & 604,889 & 5,930 & 13.12 & 3.25 & 3.90 & 7.27 \\
\hline 11 & BRS Estribo & 2 & $20 / 01 / 2017$ & Cut & 0.41 & 275,994 & 1,515 & 34.68 & 5.84 & 7.01 & 13.06 \\
\hline 12 & BRS Estribo & 2 & $20 / 01 / 2017$ & Cut & 0.51 & 244,804 & 1,765 & 28.04 & 4.88 & 5.86 & 10.92 \\
\hline 13 & BRS Estribo & 2 & $20 / 01 / 2017$ & Cut & 0.58 & 152,540 & 1,079 & 36.20 & 5.58 & 6.70 & 12.48 \\
\hline 14 & BRS Estribo & 2 & $20 / 01 / 2017$ & Flowering & -0.11 & 361,812 & 4,458 & 13.49 & 3.30 & 3.96 & 7.38 \\
\hline 15 & CG Farrapo & 2 & $20 / 01 / 2017$ & Cut & 0.06 & 309,987 & 1,931 & 28.83 & 5.49 & 6.59 & 12.28 \\
\hline 16 & CG Farrapo & 2 & $20 / 01 / 2017$ & Cut & 0.34 & 344,135 & 1,623 & 36.14 & 6.13 & 7.36 & 13.71 \\
\hline 17 & CG Farrapo & 2 & $20 / 01 / 2017$ & Cut & 0.55 & 100,587 & 985 & 32.21 & 5.25 & 6.30 & 11.74 \\
\hline 18 & CG Farrapo & 2 & $20 / 01 / 2017$ & Flowering & 0.03 & $1,331,272$ & 4,482 & 25.74 & 5.10 & 6.12 & 11.40 \\
\hline 19 & BRS Estribo & 3 & $07 / 02 / 2017$ & Cut & 0.06 & 77,069 & 1,730 & 16.05 & 3.72 & 4.46 & 8.31 \\
\hline 20 & BRS Estribo & 3 & $07 / 02 / 2017$ & Flowering & 0.10 & 686,159 & 3,648 & 22.71 & 4.67 & 5.61 & 10.45 \\
\hline 21 & CG Farrapo & 3 & $07 / 02 / 2017$ & Cut & 0.09 & 59,194 & 1,705 & 14.27 & 3.43 & 4.12 & 7.67 \\
\hline 22 & CG Farrapo & 3 & $07 / 02 / 2017$ & Flowering & 0.04 & 617,212 & 3,873 & 20.28 & 4.35 & 5.22 & 9.72 \\
\hline
\end{tabular}




\begin{tabular}{|c|c|c|c|c|c|c|c|c|c|c|c|}
\hline 23 & BRS Estribo & 4 & $24 / 02 / 2017$ & Cut & 0.07 & 99,877 & 1,627 & 19.42 & 4.22 & 5.06 & 9.43 \\
\hline 24 & BRS Estribo & 4 & $24 / 02 / 2017$ & Flowering & -0.34 & 178,186 & 2,620 & 16.11 & 3.58 & 4.30 & 8.02 \\
\hline 25 & CG Farrapo & 4 & $24 / 02 / 2017$ & Cut & 0.01 & 250,382 & 2,382 & 21.01 & 4.45 & 5.34 & 9.96 \\
\hline 26 & CG Farrapo & 4 & $24 / 02 / 2017$ & Flowering & 0.21 & 212,156 & 2,963 & 15.55 & 3.59 & 4.31 & 8.02 \\
\hline \multicolumn{12}{|c|}{ Comparison of the mean values of the cultivars ${ }^{(2)}$} \\
\hline \multicolumn{5}{|c|}{ BRS Estribo $(\mathrm{n}=13$ trials $)$} & $0.26 \mathrm{a}$ & $297,497 a$ & $2,301 \mathrm{a}$ & $25.46 \mathrm{a}$ & $4.69 \mathrm{a}$ & $5.63 \mathrm{a}$ & $10.50 \mathrm{a}$ \\
\hline \multicolumn{5}{|c|}{ CG Farrapo $(\mathrm{n}=13$ trials $)$} & $0.24 \mathrm{a}$ & $360,191 \mathrm{a}$ & $2,338 \mathrm{a}$ & $28.35 \mathrm{a}$ & $5.09 \mathrm{a}$ & $6.10 \mathrm{a}$ & $11.37 \mathrm{a}$ \\
\hline \multicolumn{12}{|c|}{ Comparison of the mean values of the sowing seasons ${ }^{(2)}$} \\
\hline \multicolumn{5}{|c|}{ Season 1 - 20/12/2016 $(\mathrm{n}=10$ trials $)$} & $0.39 \mathrm{a}$ & $324,858 \mathrm{a}$ & $2,192 \mathrm{a}$ & $31.88 \mathrm{a}$ & $5.36 \mathrm{a}$ & $6.43 \mathrm{a}$ & $11.98 \mathrm{a}$ \\
\hline \multicolumn{5}{|c|}{ Season $2-20 / 01 / 2017(n=8$ trials $)$} & $0.30 \mathrm{a}$ & $390,141 \mathrm{a}$ & $2,230 \mathrm{a}$ & $29.42 \mathrm{a}$ & $5.20 \mathrm{a}$ & $6.24 \mathrm{a}$ & $11.62 \mathrm{a}$ \\
\hline \multicolumn{5}{|c|}{ Season $3-07 / 02 / 2017(n=4$ trials $)$} & $0.07 \mathrm{~b}$ & $359,908 \mathrm{a}$ & $2,739 \mathrm{a}$ & $18.33 b$ & $4.04 \mathrm{~b}$ & $4.85 b$ & $9.04 \mathrm{~b}$ \\
\hline \multicolumn{5}{|c|}{ Season 4 - 24/02/2017 ( $\mathrm{n}=4$ trials $)$} & $-0.01 b$ & $185,150 \mathrm{a}$ & $2,398 \mathrm{a}$ & $18.02 b$ & $3.96 b$ & $4.75 b$ & $8.86 b$ \\
\hline \multicolumn{12}{|c|}{ Comparison of the mean values of the methods of fresh weight evaluation ${ }^{(2)}$} \\
\hline \multicolumn{5}{|c|}{ Cut ( $\mathrm{n}=18$ trials) } & $0.35 \mathrm{a}$ & $199,555 b$ & $1,486 b$ & $30.83 \mathrm{a}$ & $5.30 \mathrm{a}$ & $6.37 \mathrm{a}$ & $11.86 \mathrm{a}$ \\
\hline \multicolumn{5}{|c|}{ Flowering ( $\mathrm{n}=8$ trials) } & $0.03 b$ & $619,746 a$ & $4,195 \mathrm{a}$ & $18.07 \mathrm{~b}$ & $3.96 \mathrm{~b}$ & $4.75 b$ & $8.85 \mathrm{~b}$ \\
\hline
\end{tabular}

(1) Each uniformity trial of $6 \mathrm{~m} \times 7.2 \mathrm{~m}\left(43.2 \mathrm{~m}^{2}\right)$ was divided into 36 basic experimental units (BEU) of $1 \mathrm{~m} \times 1.2 \mathrm{~m}(1.2 \mathrm{~m}$ ) to form a matrix of six rows and six columns. ${ }^{(2)}$ For each statistic $\left(\rho, s^{2}, \mathrm{~m}, \mathrm{CV}\right.$, Xo e $\left.\mathrm{CV}_{\mathrm{Xo}_{\mathrm{o}}}\right)$, mean values not followed by the same letter in a column differ at 5\% significance by Student's t-test (bilateral) for independent samples.

The greater amount of fresh matter in the first two seasons compared to the last two, and the high number of uniformity trials (26), comprising a combination of two cultivars (BRS Estribo and CG Farrapo), four sowing seasons (20/12/2016, 20/01/2017, 07/02/2017 and 24/02/2017) and two methods of evaluating the fresh weight (cutting and at flowering), characterise a scenario of wide variability, affording this database representativeness and reliability in determining the optimal plot size and number of replications. According to Cargnelutti et al. (2014), such wide variability is important in studies of optimal plot size and number of replications, as it expresses the actual field conditions of the crop throughout its cycle.

Among the 26 uniformity trials, the coefficient of variation for the trial (CV) ranged from $13.12 \%$ to $45.46 \%$, with a mean value of $26.9 \%$ (Table 2). These values represent the $\mathrm{CV}$ obtained in this study for plots of one basic experimental unit, i.e. $1 \mathrm{~m} \times 1.2 \mathrm{~m}\left(1.2 \mathrm{~m}^{2}\right)$. Therefore, although it might be possible to evaluate fresh weight in plots of this size, the high values for $\mathrm{CV}$ show that the size is insufficient, as, according to the criteria of PimentelGomes (2009), the experiment would have low experimental precision. This reduction in $\mathrm{CV}$ for an increase in plot size is expected and widely proven (Paranaíba et al., 2009; Cargnelutti et al., 2014; Burin et al., 2015, 2016; Lavezo et al., 2017, 2018; Chaves et al., 2018a, b). However, the reduction is non-linear and tends to get smaller as the plot size increases (Paranaíba et al., 2009). It is therefore important to define plot size at the beginning of $\mathrm{CV}$ stabilisation. From that point on, increasing the number of replications is an alternative way of improving the experimental precision.

The mean value of the estimates of the first order spatial autocorrelation coefficient $(\rho)$, the variance $\left(\mathrm{s}^{2}\right)$, the mean $(\mathrm{m})$, the coefficient of variation for the trial (CV), the optimal plot size (Xo) and the coefficient of variation at the optimal plot size $\left(\mathrm{CV}_{\mathrm{Xo}}\right)$, for fresh weight in Sudan grass [Sorghum sudanense (Piper) Stapf.], did not differ between cultivars by Student's t-test (bilateral) (Table 2). This suggests that the experimental planning might 
be similar for the BRS Estribo and CG Farrapo cultivars. On the other hand, although there is no difference between sowing seasons in relation to the variance $\left(\mathrm{s}^{2}\right)$ and the mean $(\mathrm{m})$, the first two seasons (20 Dec and 20 Jan) had higher mean values for the first order spatial autocorrelation coefficient $(\rho)$, the coefficient of variation for the trial $(\mathrm{CV})$, the optimal plot size (Xo) and the coefficient of variation at the optimal plot size $\left(\mathrm{CV}_{\mathrm{Xo}}\right)$, compared to the last two seasons ( 7 Feb and 24 Feb). This suggests different planning for these sowing seasons. In this situation, in order to ensure sufficient experimental precision, it is important to plan the experiment based on the uniformity trial that showed the largest optimal plot size $\left(\mathrm{Xo}_{\mathrm{o}}=7.95 \mathrm{~m}^{2}\right)$ and the largest coefficient of variation at the optimal plot size $\left(\mathrm{CV}_{\mathrm{Xo}}=14.82 \%\right)$.

Of the two methods for evaluating the fresh weight (cutting and at flowering), higher mean values for variance $\left(\mathrm{s}^{2}\right)$ and for the mean $(\mathrm{m})$ were seen at flowering. This result is expected, because under the cutting management, the plants were evaluated before reaching full development. In practice, the fresh weight at flowering should be compared with the accumulated fresh weight from the cuttings. Greater mean values for the first order spatial autocorrelation coefficient $(\rho)$, the coefficient of variation for the trial $(\mathrm{CV})$, the optimal plot size (Xo) and the coefficient of variation at the optimal plot size $\left(\mathrm{CV}_{\mathrm{Xo}_{0}}\right)$ were obtained for the method of evaluation by cutting. This confirms the different planning for the two methods of evaluating the fresh weight. In this context, the above inferences are confirmed, i.e. planning the experiment based on the trial with the greatest optimal plot size $\left(\mathrm{Xo}_{\mathrm{O}}=7.95\right.$ $\mathrm{m}^{2}$ ) and the highest coefficient of variation at the optimal plot size $\left(\mathrm{CV}_{\mathrm{Xo}}=14.82 \%\right)$ is suitable for guaranteeing sufficient experimental precision in the different situations.

Given this scenario of variability between the 26 uniformity trials, between the sowing seasons and between the methods of evaluation, it can be inferred that the optimal plot size to evaluate fresh matter in Sudan grass was $7.95 \mathrm{~m}^{2}$ and that the coefficient of variation at the optimal plot size was $14.82 \%$. In experiments involving the evaluation of Sudan grass, the plot sizes used by Borges et al. (2014) and Aker et al. (2016) were superior to that obtained in the present study, suggesting the reliability of the published information. On the other hand, in other studies smaller plots were used, i.e. $7 \mathrm{~m}^{2}$ (Penna et al., 2010) and $5 \mathrm{~m}^{2}$ (Arenhardt et al., 2015, 2016). The coefficient of variation for the fresh weight ranged from $29.26 \%$ to $44.02 \%$ (Penna et al., 2010) and was not mentioned in the studies by Arenhardt et al. $(2015,2016)$. The comparison between the optimal plot sizes obtained in this study and the plot sizes used in the above works should be viewed with caution, as there are differences regarding the effective area of the plot used in the evaluations, the type of management and the presence of other species together with the Sudan grass.

No studies were found of the optimal plot size to evaluate fresh weight in Sudan grass [Sorghum sudanense (Piper) Stapf.] for comparison with those obtained in this study. However, for other groundcover plants, the optimal plot size to evaluate fresh weight in black oats was $4.14 \mathrm{~m}^{2}$ (Cargnelutti et al., 2014), in millet for different periods of evaluation it was $4.46 \mathrm{~m}^{2}$ (Burin et al., 2015), and in millet for different sowing and cutting seasons, it was 4.97 $\mathrm{m}^{2}$ (Burin et al., 2016). In white oats the plot sizes for fresh and dry weight were $1.66 \mathrm{~m}^{2}$ and 1.73 $\mathrm{m}^{2}$ respectively (Lavezo et al., 2018). The optimal plot sizes to evaluate fresh and dry weight in rye were $3.43 \mathrm{~m}^{2}$ and $3.82 \mathrm{~m}^{2}$ respectively (Chaves et al., 2018b). To evaluate grain yield, the plot size for white oats was $1.57 \mathrm{~m}^{2}$ (Lavezo et al., 2017) and for rye it was $6.08 \mathrm{~m}^{2}$ (Chaves et al., 2018a).

For experiments in a completely randomised design(CRD), in scenarios comprising a combination of $i$ treatments $(i=3,4, \ldots, 50)$ and $d$ minimum differences between the mean values of those treatments detected as significant at 0.05 probability by Tukey's test, expressed as a percentage of the mean value of the experiment $(\mathrm{d}=10 \%, 12 \%, 14 \%$, $16 \%, 18 \%, 20 \%, 22 \%, 24 \%, 26 \%, 28 \%, 30 \%)$, the 
number of replications to evaluate the fresh weight of Sudan grass varied between 3.85 (3 treatments and $\mathrm{d}=30 \%$ ) and 70.15 (50 treatments and $\mathrm{d}=10 \%$ ) (Table 3). For experiments in a randomised block design (RBD), the number of replications varied between 4.29 ( 3 treatments and $\mathrm{d}=30 \%$ ) and 70.15 (50 treatments and $\mathrm{d}=10 \%$ ) (Table 4). Therefore, even with a coefficient of variation of $14.82 \%$, classified as medium (Pimentel-Gomes, 2009), and irrespective of the experimental design, obtaining an accuracy of $10 \%$ (greater precision) is impractical due to the high number of replications. Based on the optimal plot size $\left(\mathrm{Xo}_{\mathrm{o}}=7.95 \mathrm{~m}^{2}\right)$, the user of this information can establish the relationship between $\mathrm{i}, \mathrm{d}$ and the number of replications that can be carried out. Although, in practice, integer values should be used for the number of replications, these were expressed to two decimal places (Tables 3 and 4) to demonstrate the differences between the combinations of $i$ and $d$.
Regardless of the experimental design (CRD or $\mathrm{RBD}$ ), for fixed values of $\mathrm{Xo}, \mathrm{CV}_{\mathrm{Xo}}$ and $\mathrm{d}$, there is an increase in the number of replications (r) for an increase in the number of treatments (Tables 3 and 4). For fixed values of $\mathrm{Xo}, \mathrm{CV}_{\mathrm{Xo}}, \mathrm{i}$ and $\mathrm{d}$, more replications are necessary in RBD than in CRD. For example, for $\mathrm{i}=3$ and $\mathrm{d}=10 \%, 25.65$ replications would be necessary in RBD and 25.15 in CRD. For the same value of $d$, the difference in the number of replications between the two designs decreases with an increase in the number of treatments. Therefore, the greater the number of treatments, the closer the number of replications between RBD and CRD. For example, to evaluate $i=50$ with $d=30 \%$, 7.93 replications would be needed in both designs (CRD and RBD) (Tables 3 and 4). A similar pattern for these relationships was found by Cargnelutti et al. (2014), Burin et al. (2015, 2016), Lavezo et al. (2017, 2018) and Chaves et al. (2018a, b).

Table 3

Number of replications for experiments in a completely randomised design, in scenarios comprising a combination of $i$ treatments $(i=3,4, \ldots, 50)$ and $d$ minimum differences between the mean value of those treatments detected as significant at $\mathbf{5 \%}$ probability by Tukey's test, expressed as a percentage of the mean value of the experiment $(\mathrm{d}=10 \%, 12 \%, 14 \%, 16 \%, 18 \%, 20 \%, 22 \%, 24 \%, 26 \%, 28 \%, 30 \%)$ to evaluate fresh weight in Sudan grass [Sorghum sudanense (Piper) Stapf.], based on the optimal plot size $\left(\mathrm{Xo}=7.95 \mathrm{~m}^{2}\right)$ and the coefficient of variation at the optimal plot size $\left(\mathrm{CV}_{\mathrm{x}_{0}}=14.82 \%\right)$

\begin{tabular}{cccccccccccc}
\hline $\mathrm{i}$ & $10 \%$ & $12 \%$ & $14 \%$ & $16 \%$ & $18 \%$ & $20 \%$ & $22 \%$ & $24 \%$ & $26 \%$ & $28 \%$ & $30 \%$ \\
\hline 3 & 25.15 & 17.79 & 13.36 & 10.48 & 8.52 & 7.13 & 6.10 & 5.32 & 4.72 & 4.24 & 3.85 \\
4 & 29.85 & 21.00 & 15.67 & 12.21 & 9.85 & 8.16 & 6.92 & 5.97 & 5.24 & 4.67 & 4.21 \\
5 & 33.43 & 23.45 & 17.44 & 13.54 & 10.87 & 8.96 & 7.56 & 6.49 & 5.66 & 5.01 & 4.49 \\
6 & 36.33 & 25.44 & 18.87 & 14.61 & 11.70 & 9.62 & 8.08 & 6.91 & 6.01 & 5.30 & 4.72 \\
7 & 38.78 & 27.12 & 20.09 & 15.53 & 12.40 & 10.17 & 8.53 & 7.28 & 6.31 & 5.54 & 4.92 \\
8 & 40.89 & 28.57 & 21.14 & 16.32 & 13.02 & 10.66 & 8.92 & 7.59 & 6.57 & 5.76 & 5.10 \\
9 & 42.76 & 29.85 & 22.07 & 17.02 & 13.56 & 11.09 & 9.26 & 7.88 & 6.80 & 5.95 & 5.27 \\
10 & 44.43 & 31.00 & 22.90 & 17.65 & 14.05 & 11.48 & 9.58 & 8.13 & 7.01 & 6.13 & 5.41 \\
11 & 45.94 & 32.04 & 23.66 & 18.22 & 14.49 & 11.83 & 9.86 & 8.37 & 7.21 & 6.29 & 5.55 \\
12 & 47.32 & 32.99 & 24.35 & 18.74 & 14.90 & 12.15 & 10.12 & 8.58 & 7.38 & 6.44 & 5.67 \\
13 & 48.59 & 33.86 & 24.98 & 19.22 & 15.27 & 12.45 & 10.37 & 8.78 & 7.55 & 6.57 & 5.79 \\
14 & 49.76 & 34.67 & 25.57 & 19.67 & 15.62 & 12.73 & 10.59 & 8.97 & 7.70 & 6.70 & 5.90
\end{tabular}

continue 


\begin{tabular}{|c|c|c|c|c|c|c|c|c|c|c|c|}
\hline 15 & 50.86 & 35.43 & 26.12 & 20.09 & 15.95 & 12.99 & 10.80 & 9.14 & 7.85 & 6.83 & 6.00 \\
\hline 16 & 51.89 & 36.13 & 26.64 & 20.48 & 16.25 & 13.23 & 11.00 & 9.30 & 7.99 & 6.94 & 6.10 \\
\hline 17 & 52.85 & 36.80 & 27.12 & 20.84 & 16.54 & 13.46 & 11.19 & 9.46 & 8.11 & 7.05 & 6.19 \\
\hline 18 & 53.76 & 37.43 & 27.58 & 21.19 & 16.81 & 13.68 & 11.36 & 9.60 & 8.24 & 7.15 & 6.28 \\
\hline 19 & 54.62 & 38.02 & 28.01 & 21.52 & 17.07 & 13.88 & 11.53 & 9.74 & 8.35 & 7.25 & 6.36 \\
\hline 20 & 55.44 & 38.59 & 28.43 & 21.83 & 17.31 & 14.08 & 11.69 & 9.87 & 8.46 & 7.34 & 6.44 \\
\hline 21 & 56.22 & 39.12 & 28.82 & 22.13 & 17.55 & 14.27 & 11.84 & 10.00 & 8.57 & 7.43 & 6.52 \\
\hline 22 & 56.96 & 39.64 & 29.19 & 22.41 & 17.77 & 14.45 & 11.99 & 10.12 & 8.67 & 7.52 & 6.59 \\
\hline 23 & 57.67 & 40.13 & 29.55 & 22.69 & 17.98 & 14.62 & 12.13 & 10.24 & 8.77 & 7.60 & 6.66 \\
\hline 24 & 58.35 & 40.60 & 29.89 & 22.95 & 18.18 & 14.78 & 12.26 & 10.35 & 8.86 & 7.68 & 6.73 \\
\hline 25 & 59.01 & 41.05 & 30.22 & 23.20 & 18.38 & 14.94 & 12.39 & 10.45 & 8.95 & 7.75 & 6.79 \\
\hline 26 & 59.63 & 41.48 & 30.54 & 23.44 & 18.57 & 15.09 & 12.51 & 10.56 & 9.03 & 7.83 & 6.85 \\
\hline 27 & 60.24 & 41.90 & 30.84 & 23.67 & 18.75 & 15.23 & 12.63 & 10.65 & 9.12 & 7.90 & 6.92 \\
\hline 28 & 60.82 & 42.30 & 31.14 & 23.89 & 18.93 & 15.37 & 12.75 & 10.75 & 9.20 & 7.97 & 6.97 \\
\hline 29 & 61.38 & 42.69 & 31.42 & 24.11 & 19.10 & 15.51 & 12.86 & 10.84 & 9.28 & 8.03 & 7.03 \\
\hline 30 & 61.93 & 43.07 & 31.70 & 24.32 & 19.26 & 15.64 & 12.97 & 10.93 & 9.35 & 8.10 & 7.09 \\
\hline 31 & 62.45 & 43.43 & 31.96 & 24.52 & 19.42 & 15.77 & 13.07 & 11.02 & 9.42 & 8.16 & 7.14 \\
\hline 32 & 62.96 & 43.78 & 32.22 & 24.72 & 19.57 & 15.89 & 13.17 & 11.10 & 9.49 & 8.22 & 7.19 \\
\hline 33 & 63.46 & 44.13 & 32.47 & 24.91 & 19.72 & 16.01 & 13.27 & 11.18 & 9.56 & 8.28 & 7.24 \\
\hline 34 & 63.94 & 44.46 & 32.71 & 25.09 & 19.87 & 16.13 & 13.37 & 11.26 & 9.63 & 8.33 & 7.29 \\
\hline 35 & 64.40 & 44.78 & 32.95 & 25.27 & 20.01 & 16.24 & 13.46 & 11.34 & 9.69 & 8.39 & 7.34 \\
\hline 36 & 64.85 & 45.09 & 33.18 & 25.44 & 20.14 & 16.35 & 13.55 & 11.42 & 9.76 & 8.44 & 7.38 \\
\hline 37 & 65.30 & 45.40 & 33.40 & 25.61 & 20.28 & 16.46 & 13.64 & 11.49 & 9.82 & 8.50 & 7.43 \\
\hline 38 & 65.72 & 45.69 & 33.62 & 25.78 & 20.41 & 16.56 & 13.72 & 11.56 & 9.88 & 8.55 & 7.47 \\
\hline 39 & 66.14 & 45.98 & 33.83 & 25.94 & 20.53 & 16.67 & 13.81 & 11.63 & 9.94 & 8.60 & 7.51 \\
\hline 40 & 66.55 & 46.27 & 34.04 & 26.10 & 20.66 & 16.77 & 13.89 & 11.70 & 10.00 & 8.64 & 7.56 \\
\hline 41 & 66.95 & 46.54 & 34.24 & 26.25 & 20.78 & 16.86 & 13.97 & 11.76 & 10.05 & 8.69 & 7.60 \\
\hline 42 & 67.34 & 46.81 & 34.43 & 26.40 & 20.89 & 16.96 & 14.04 & 11.83 & 10.11 & 8.74 & 7.64 \\
\hline 43 & 67.72 & 47.07 & 34.63 & 26.55 & 21.01 & 17.05 & 14.12 & 11.89 & 10.16 & 8.78 & 7.68 \\
\hline 44 & 68.09 & 47.33 & 34.81 & 26.69 & 21.12 & 17.14 & 14.19 & 11.95 & 10.21 & 8.83 & 7.72 \\
\hline 45 & 68.45 & 47.58 & 35.00 & 26.83 & 21.23 & 17.23 & 14.27 & 12.01 & 10.26 & 8.87 & 7.75 \\
\hline 46 & 68.80 & 47.82 & 35.18 & 26.97 & 21.34 & 17.31 & 14.34 & 12.07 & 10.31 & 8.92 & 7.79 \\
\hline 47 & 69.15 & 48.06 & 35.35 & 27.10 & 21.44 & 17.40 & 14.41 & 12.13 & 10.36 & 8.96 & 7.83 \\
\hline 48 & 69.49 & 48.30 & 35.52 & 27.23 & 21.55 & 17.48 & 14.48 & 12.19 & 10.41 & 9.00 & 7.86 \\
\hline 49 & 69.82 & 48.53 & 35.69 & 27.36 & 21.65 & 17.56 & 14.54 & 12.24 & 10.46 & 9.04 & 7.90 \\
\hline 50 & 70.15 & 48.76 & 35.86 & 27.49 & 21.75 & 17.64 & 14.61 & 12.30 & 10.50 & 9.08 & 7.93 \\
\hline
\end{tabular}


Table 4

Number of replications, for experiments in a randomised block design, in scenarios comprising a combination of $i$ treatments $(i=3,4, \ldots, 50)$ and $d$ minimum differences between the mean value of those treatments detected as significant at $5 \%$ probability by Tukey's test, expressed as a percentage of the mean value of the experiment $(\mathrm{d}=10 \%, 12 \%, 14 \%, 16 \%, 18 \%, 20 \%, 22 \%, 24 \%, 26 \%, 28 \%, 30 \%)$ to evaluate fresh weight in Sudan grass [Sorghum sudanense (Piper) Stapf.], based on the optimal plot size $\left(X 0=7.95 \mathrm{~m}^{2}\right)$ and the coefficient of variation at the optimal plot size $\left(\mathrm{CV}_{\mathrm{X}_{0}}=\mathbf{1 4 . 8 2 \%}\right)$

\begin{tabular}{|c|c|c|c|c|c|c|c|c|c|c|c|}
\hline $\mathrm{i}$ & $10 \%$ & $12 \%$ & $14 \%$ & $16 \%$ & $18 \%$ & $20 \%$ & $22 \%$ & $24 \%$ & $26 \%$ & $28 \%$ & $30 \%$ \\
\hline 3 & 25.65 & 18.29 & 13.85 & 10.98 & 9.02 & 7.61 & 6.59 & 5.79 & 5.18 & 4.70 & 4.29 \\
\hline 4 & 30.13 & 21.28 & 15.95 & 12.50 & 10.13 & 8.44 & 7.20 & 6.26 & 5.53 & 4.95 & 4.49 \\
\hline 5 & 33.61 & 23.63 & 17.62 & 13.72 & 11.05 & 9.15 & 7.74 & 6.67 & 5.85 & 5.19 & 4.67 \\
\hline 6 & 36.46 & 25.57 & 19.00 & 14.75 & 11.83 & 9.75 & 8.21 & 7.05 & 6.14 & 5.43 & 4.86 \\
\hline 7 & 38.88 & 27.21 & 20.19 & 15.63 & 12.50 & 10.27 & 8.63 & 7.38 & 6.41 & 5.64 & 5.03 \\
\hline 8 & 40.97 & 28.65 & 21.22 & 16.40 & 13.10 & 10.74 & 9.00 & 7.67 & 6.65 & 5.84 & 5.18 \\
\hline 9 & 42.82 & 29.91 & 22.13 & 17.08 & 13.62 & 11.15 & 9.33 & 7.94 & 6.87 & 6.01 & 5.33 \\
\hline 10 & 44.48 & 31.05 & 22.95 & 17.70 & 14.10 & 11.53 & 9.63 & 8.19 & 7.07 & 6.18 & 5.47 \\
\hline 11 & 45.98 & 32.08 & 23.70 & 18.26 & 14.54 & 11.87 & 9.91 & 8.41 & 7.25 & 6.33 & 5.59 \\
\hline 12 & 47.35 & 33.02 & 24.38 & 18.78 & 14.94 & 12.19 & 10.16 & 8.62 & 7.42 & 6.47 & 5.71 \\
\hline 13 & 48.62 & 33.89 & 25.01 & 19.25 & 15.31 & 12.48 & 10.40 & 8.81 & 7.58 & 6.61 & 5.82 \\
\hline 14 & 49.79 & 34.70 & 25.60 & 19.70 & 15.65 & 12.76 & 10.62 & 9.00 & 7.73 & 6.73 & 5.93 \\
\hline 15 & 50.89 & 35.45 & 26.15 & 20.11 & 15.97 & 13.01 & 10.83 & 9.17 & 7.87 & 6.85 & 6.03 \\
\hline 16 & 51.91 & 36.16 & 26.66 & 20.50 & 16.27 & 13.26 & 11.02 & 9.33 & 8.01 & 6.96 & 6.12 \\
\hline 17 & 52.87 & 36.82 & 27.14 & 20.86 & 16.56 & 13.48 & 11.21 & 9.48 & 8.13 & 7.07 & 6.21 \\
\hline 18 & 53.78 & 37.45 & 27.60 & 21.21 & 16.83 & 13.70 & 11.38 & 9.62 & 8.25 & 7.17 & 6.30 \\
\hline 19 & 54.64 & 38.04 & 28.03 & 21.54 & 17.08 & 13.90 & 11.55 & 9.76 & 8.37 & 7.27 & 6.38 \\
\hline 20 & 55.46 & 38.60 & 28.44 & 21.85 & 17.33 & 14.10 & 11.71 & 9.89 & 8.48 & 7.36 & 6.46 \\
\hline 21 & 56.23 & 39.14 & 28.83 & 22.14 & 17.56 & 14.28 & 11.86 & 10.01 & 8.58 & 7.45 & 6.53 \\
\hline 22 & 56.98 & 39.65 & 29.20 & 22.43 & 17.78 & 14.46 & 12.00 & 10.13 & 8.68 & 7.53 & 6.60 \\
\hline 23 & 57.68 & 40.14 & 29.56 & 22.70 & 17.99 & 14.63 & 12.14 & 10.25 & 8.78 & 7.61 & 6.67 \\
\hline 24 & 58.36 & 40.61 & 29.90 & 22.96 & 18.20 & 14.79 & 12.27 & 10.36 & 8.87 & 7.69 & 6.74 \\
\hline 25 & 59.02 & 41.06 & 30.23 & 23.21 & 18.39 & 14.95 & 12.40 & 10.46 & 8.96 & 7.76 & 6.80 \\
\hline 26 & 59.64 & 41.49 & 30.55 & 23.45 & 18.58 & 15.10 & 12.52 & 10.57 & 9.04 & 7.84 & 6.86 \\
\hline 27 & 60.25 & 41.91 & 30.85 & 23.68 & 18.76 & 15.24 & 12.64 & 10.66 & 9.13 & 7.91 & 6.92 \\
\hline 28 & 60.83 & 42.31 & 31.15 & 23.90 & 18.93 & 15.38 & 12.76 & 10.76 & 9.21 & 7.97 & 6.98 \\
\hline 29 & 61.39 & 42.70 & 31.43 & 24.12 & 19.10 & 15.52 & 12.87 & 10.85 & 9.28 & 8.04 & 7.04 \\
\hline 30 & 61.93 & 43.07 & 31.70 & 24.32 & 19.27 & 15.65 & 12.97 & 10.94 & 9.36 & 8.10 & 7.09 \\
\hline 31 & 62.46 & 43.44 & 31.97 & 24.53 & 19.42 & 15.78 & 13.08 & 11.03 & 9.43 & 8.17 & 7.15 \\
\hline 32 & 62.97 & 43.79 & 32.23 & 24.72 & 19.58 & 15.90 & 13.18 & 11.11 & 9.50 & 8.22 & 7.20 \\
\hline 33 & 63.46 & 44.13 & 32.48 & 24.91 & 19.73 & 16.02 & 13.28 & 11.19 & 9.57 & 8.28 & 7.25 \\
\hline 34 & 63.94 & 44.46 & 32.72 & 25.10 & 19.87 & 16.13 & 13.37 & 11.27 & 9.64 & 8.34 & 7.29 \\
\hline 35 & 64.41 & 44.78 & 32.95 & 25.28 & 20.01 & 16.25 & 13.46 & 11.35 & 9.70 & 8.39 & 7.34 \\
\hline 36 & 64.86 & 45.10 & 33.18 & 25.45 & 20.15 & 16.36 & 13.55 & 11.42 & 9.76 & 8.45 & 7.39 \\
\hline 37 & 65.30 & 45.40 & 33.41 & 25.62 & 20.28 & 16.46 & 13.64 & 11.49 & 9.82 & 8.50 & 7.43 \\
\hline
\end{tabular}




\begin{tabular}{cccccccccccc}
\multicolumn{2}{c}{ continuation } \\
38 & 65.73 & 45.70 & 33.62 & 25.78 & 20.41 & 16.57 & 13.73 & 11.57 & 9.88 & 8.55 & 7.48 \\
39 & 66.15 & 45.99 & 33.83 & 25.95 & 20.54 & 16.67 & 13.81 & 11.63 & 9.94 & 8.60 & 7.52 \\
40 & 66.55 & 46.27 & 34.04 & 26.10 & 20.66 & 16.77 & 13.89 & 11.70 & 10.00 & 8.65 & 7.56 \\
41 & 66.95 & 46.54 & 34.24 & 26.26 & 20.78 & 16.87 & 13.97 & 11.77 & 10.06 & 8.70 & 7.60 \\
42 & 67.34 & 46.81 & 34.44 & 26.40 & 20.90 & 16.96 & 14.05 & 11.83 & 10.11 & 8.74 & 7.64 \\
43 & 67.72 & 47.08 & 34.63 & 26.55 & 21.01 & 17.05 & 14.12 & 11.90 & 10.16 & 8.79 & 7.68 \\
44 & 68.09 & 47.33 & 34.82 & 26.69 & 21.13 & 17.14 & 14.20 & 11.96 & 10.21 & 8.83 & 7.72 \\
45 & 68.45 & 47.58 & 35.00 & 26.83 & 21.24 & 17.23 & 14.27 & 12.02 & 10.27 & 8.88 & 7.76 \\
46 & 68.81 & 47.83 & 35.18 & 26.97 & 21.34 & 17.32 & 14.34 & 12.08 & 10.32 & 8.92 & 7.79 \\
47 & 69.15 & 48.07 & 35.35 & 27.10 & 21.45 & 17.40 & 14.41 & 12.13 & 10.36 & 8.96 & 7.83 \\
48 & 69.49 & 48.30 & 35.53 & 27.24 & 21.55 & 17.49 & 14.48 & 12.19 & 10.41 & 9.00 & 7.86 \\
49 & 69.83 & 48.53 & 35.70 & 27.36 & 21.65 & 17.57 & 14.54 & 12.25 & 10.46 & 9.04 & 7.90 \\
50 & 70.15 & 48.76 & 35.86 & 27.49 & 21.75 & 17.65 & 14.61 & 12.30 & 10.51 & 9.08 & 7.93 \\
\hline
\end{tabular}

It is not possible to conduct experiments with 7.93 replications, and a whole number of replications must be chosen. So, for example, setting $r$ equal to eight replications, a value greater than the four replications used in the experiments by Penna et al. (2010), Borges et al. (2014), Arenhardt et al. $(2015,2016)$ and Aker et al. (2016), the minimum significant difference (d) by Tukey's test, expressed as a percentage of the mean value of the experiment, can be estimated by the expression: $\mathrm{d}=\left(\mathrm{q}_{\alpha(\mathrm{i} ; \mathrm{DFE})} \mathrm{CV}\right) / \sqrt{\mathrm{r}}$. Therefore, for 50 treatments, the completely randomised design would give $\mathrm{d}=\left(\mathrm{q}_{5 \%(50 ; 150)} \times 14.82\right) / \sqrt{8}=(5.7710567 \times 14.82) / \sqrt{8}=30.24 \%$ and the randomised block design, $\mathrm{d}=\left(\mathrm{q}_{5 \%(50 ; 47)} \times 14.82\right) / \sqrt{8}=(5.7736023 \times 14.82) / \sqrt{8}=30.25 \%$. As such, it can be inferred that to evaluate the fresh weight of Sudan grass in a completely randomised or randomised block design with up to 50 treatments, eight replications are sufficient to identify as significant at 0.05 probability by Tukey's test, differences between the mean value of each treatment of $30.2 \%$ of the mean value of the experiment.

\section{Conclusions}

The optimal plot size to evaluate fresh weight in Sudan grass is $7.95 \mathrm{~m}^{2}$. Eight replications, to evaluate up to 50 treatments in a completely randomised or randomised block design, are sufficient to identify as significant at 0.05 probability by Tukey's test, differences between the mean value of each treatment of $30.2 \%$ of the mean value of the experiment.

\section{Acknowledgements}

The authors wish to thank the Conselho Nacional de Desenvolvimento Científico e Tecnológico (CNPq - Process no 401045/20161 and 304652/2017-2) and the Coordenação de Aperfeiçoamento de Pessoal de Nível Superior (CAPES) for granting the scholarships, and the Fundação de Amparo à Pesquisa do Estado do Rio Grande do Sul (FAPERGS) for the scientific initiation scholarship. The authors would also like to thank the scholarship students and volunteers for their help in collecting the data. 


\section{References}

Aker, A. M., Passos, A. M. A., Marcolan, A. L., Santos, F. C., Cipriani, H. N., \& Vargas, L. A. (2016). Plantas de cobertura sobre atributos agronômicos do milho na região sudoeste da Amazônia. Revista Brasileira de Milho e Sorgo, 15(3), 532-543. doi: 10.18512/19806477/rbms.v15n3p531-542

Alvares, C. A., Stape, J. L., Sentelhas, P. C., Gonçalves, J. L. M., \& Sparovek, G. (2013). Köppen's climate classification map for Brazil. Meteorologische Zeitschrift, 22(6), 711-728. doi: 10.1127/09412948/2013/0507

Arenhardt, E. G., Silva, J. A. G., Gewehr, E., Arenhardt, L. G., Arenhardt, C. L., \& Nonnenmacher, G. (2016). CG FARRAPO: a sudangrass cultivar with high biomass and grain yields. Crop Breeding and Applied Biotechnology, 16(2), 158-162. doi: 10.1590/1984-70332016v16n2c24

Arenhardt, E. G., Silva, J. A. G., Gewehr, E., Arenhardt, L. G., Arenhardt, C. L., \& Nonnenmacher, G. (2015). CG PICAÇO: a new cultivar of sudangrass with high forage performance and seed yield. Crop Breeding and Applied Biotechnology, 15(1), 51-55. doi: 10.1590/1984-70332015v15n1c10

Borges, W. L. B., Freitas, R. S., Mateus, G. P., Sá, M. E., \& Alves, M. C. (2014). Supressão de plantas daninhas utilizando plantas de cobertura do solo. Planta Daninha, 32(4), 755-763. doi: 10.1590/ S0100-83582014000400010

Burin, C., Cargnelutti, A., Fº, Alves, B. M., Toebe, M., Kleinpaul, J. A., \& Neu, I. M. M. (2015). Tamanho de parcela e número de repetições na cultura do milheto em épocas de avaliação. Bragantia, 74(3), 261-269. doi: 10.1590/1678-4499.0465

Burin, C., Cargnelutti, A., Fº., Alves, B. M., Toebe, M., \& Kleinpaul, J. A. (2016). Plot size and number of replicates in times of sowing and cuts of millet. Revista Brasileira de Engenharia Agrícola e Ambiental, 20(2), 119-127. doi: 10.1590/1807-1929/ agriambi.v20n2p119-127

Cargnelutti, A., Fo., Alves, B. M., Toebe, M., Burin, C., Santos, G. O., Facco, G.,... Stefanello, R. B. (2014). Tamanho de parcela e número de repetições em aveia preta. Ciência Rural, 44(10), 1732-1739. doi: 10.1590/0103-8478cr20131466

Chaves, G. G., Cargnelutti, A., Fo ., Bem, C. M., Bandeira, C. T., Silveira, D. L., \& Thomasi, R. M. (2018a). Plot size and number of replications for evaluation of the yield of grains in cultivars and seasons of sowing of rye. Journal of Agricultural Science, 10(1), 122-132. doi: 10.5539/jas.v10n1p122

Chaves, G. G., Cargnelutti, A., Fº., Carini, F., Kleinpaul, J. A., Neu, I. M. M., \& Procedi, A. (2018b). Tamanho de parcela e número de repetições para avaliação de caracteres vegetativos em centeio. Revista Brasileira de Ciências Agrárias, 13(3), e5563. doi:10.5039/ agraria.v13i3a5563

Cruz, C. D. (2016). Genes Software - extended and integrated with the R, Matlab and Selegen. Acta Scientiarum Agronomy, 38(4), 547-552. doi: 10.4025/actasciagron.v38i4.32629

Lavezo, A., Cargnelutti, A., Fº., Alves, B. M., Schabarum, D. E., Silveira, D. L., \& Chaves, G. G. (2018). Plot size and number of replications to assess the vegetable matter in oat. Comunicata Scientiae, 9(2), 252-263. doi: 10.14295/CS.v9i2.2671

Lavezo, A., Cargnelutti, A., Fº., Bem, C. M., Burin, C., Kleinpaul, J. A., \& Pezzini, R. V. (2017). Plot size and number of replications to evaluate the grain yield in oat cultivars. Bragantia, 76(4), 512-520. doi: 10.1590/1678-4499.2016.410

Paranaíba, P. F., Ferreira, D. F., \& Morais, A. R. (2009). Tamanho ótimo de parcelas experimentais: proposição de métodos de estimação. Revista Brasileira de Biometria, 27(2), 255-268.

Penna, A. G., Borges, A. L. C. C., Gonçalves, L. C., Rodrigues, J. A. S., Gomes, S. P., Penna, C. F. A. M.,... Silva, R. R. (2010). Produção de seis híbridos de sorgo com capim-sudão avaliados em três cortes e em duas épocas de semeadura. Revista Brasileira de Milho e Sorgo, 9(1), 93-105. doi: 10.18512/19806477/rbms.v9n01p93-105

Pimentel-Gomes, F. (2009). Curso de estatística experimental (15a ed.). Piracicaba: FEALQ.

R Development Core Team (2018). R: A Language and Environment for Statistical Computing. Vienna: R Foundation for Statistical Computing.

Santos, H. G., Jacomine, P. K. T., Anjos, L. H. C., Oliveira, V. A., Lumbreras, J. F., Coelho, M. R.,... Oliveira, J. B. (2013). Sistema brasileiro de classificação de solos (3a ed). Brasília: EMBRAPA.

Silveira, M. C. T., Sant'anna, D. M., Montardo, D. P., \& Trentin, G. (2015). Aspectos relativos à implantação e manejo de capim-sudão BRS Estribo. (EMBRAPA - Comunicado Técnico, 89). Bagé: EMBRAPA Pecuária Sul. 
